\title{
Species richness and cell-size distribution: size structure of phytoplankton communities
}

\author{
Pedro Cermeñoo ${ }^{1, *}$, Francisco G. Figueiras ${ }^{2}$ \\ ${ }^{1}$ Environmental Biophysics and Molecular Ecology, Institute of Marine and Coastal Sciences, Rutgers University, \\ 71 Dudley Road, New Brunswick, New Jersey 08901-8521, USA \\ ${ }^{2}$ Instituto de Investigacións Mariñas, Consejo Superior de Investigaciones Cientificas, CSIC, Eduardo Cabello 6, \\ 36208 Vigo, Spain
}

\begin{abstract}
If the size dependence of species richness varies across ecosystems, it should be reflected in the size distribution of total abundance. Using a database of phytoplankton abundance, species composition and cell size from coastal, shelf and open-ocean environments, we show that the biogeographical patterns of phytoplankton size distribution in the ocean are a result of systematic changes in the relationship between species richness and cell size. Our results indicate that, regardless of the environmental conditions, population abundance decreases consistently to the $-3 / 4$ power of cell size. By contrast, marine phytoplankton diversity peaks at small sizes in oligotrophic waters but is either a log-normal function or independent of cell size in eutrophic systems. It is argued that, operating on evolutionary time scales, size-dependent biophysical constraints for resource acquisition are reflected in the size distribution of species richness and consequently in the size structure of phytoplankton communities in the ocean. These findings indicate that the way in which biological diversity changes with body size is crucial to a better understanding of the structure and functioning of microbial plankton communities and how energy flows through pelagic ecosystems.
\end{abstract}

KEY WORDS: Macroecology $\cdot$ Community structure $\cdot$ Species richness $\cdot$ Population abundance Cell size $\cdot$ Self-organization $\cdot$ Phytoplankton

\section{INTRODUCTION}

In many community assemblages, the abundance of organisms $\left(N_{t}\right)$ scales to body size $(M)$ according to the equation:

$$
N_{t}=C_{t} M^{\alpha}
$$

where $C_{t}$ is the number of individuals at a reference size and $\alpha$, the size-scaling exponent, is an index representative of community size structure (Peters 1983, Rodríguez 1994, Brown 1995). Empirical observations from marine ecosystems indicate that $\alpha$ exhibits considerable variability (ca. $-3 / 4$ to -1 ) as a result of environmental conditions or the ecosystem's productivity (Sheldon et al. 1972, Sprules \& Munawar 1986, Cavender-Bares et al. 2001, Irwin et al. 2006). Yet the mechanisms that control this variability, and thus community size structure, remain largely unknown.
The total number of individuals $\left(N_{t}\right)$ in a community results from multiplying the number of species $(S)$ by their population abundances $\left(N_{p}\right)$. According to this, the relationship between total abundance and body size, defined on a continuum, may be parameterized by the equation:

$$
N_{t}=N_{p} \times S(M)=C_{p} M^{\beta} \times S(M)
$$

where $C_{p}$ is a case-specific proportionality constant, $\beta$ is the allometric exponent of population abundance, and $S(M)$ represents the size dependence of species richness, which may take either a log-normal distribution or a decreasing power function, or be a constant. Knowing the shape of $S(M)$ leads to the integration of Eq. (2), which yields the total number of individuals within any given size class. So far we can assume that, whatever shape it takes, $S(M)$ is dependent on the resource conditions of the ecosystem. Therefore, if 
$S(M)$ varies across ecosystems, it should be reflected in the size distribution of total abundance. Here we test this hypothesis by analyzing the allometric scalings of total and population abundance as well as the size distribution of species richness using phytoplankton communities from coastal, shelf and open-ocean environments.

\section{MATERIALS AND METHODS}

Sampling. Data on nano- (2 to $20 \mu \mathrm{m}$ equivalent spherical diameter [ESD]) and microphytoplankton (>20 $\mu \mathrm{m}$ ESD) assemblages, in terms of species composition, abundance and cell size, were compiled from different databases. Water samples for species identification and abundance estimation were collected in the Ría de Vigo $(n=150)$, the Atlantic Iberian shelf $(n=50)$, the English Channel $(\mathrm{n}=451)$, the Baltic Proper $(\mathrm{n}=$ 957), the Bothnia Gulf $(\mathrm{n}=211)$ and 4 meridional transects (Atlantic Meridional Transects [AMT] 1 to 4) from $48^{\circ} \mathrm{N}$ to $50^{\circ} \mathrm{S}$ in the Atlantic Ocean. To further constrain variability in environmental conditions, the AMT data set was partitioned into different regions according to their physical, chemical and biological features. Five oceanographic regions, namely, North Temperate (35 to $48^{\circ} \mathrm{N}, \mathrm{n}=11$ ), North Subtropical gyre (25 to $\left.35^{\circ} \mathrm{N}, \mathrm{n}=14\right)$, Equatorial $\left(25^{\circ} \mathrm{N}\right.$ to $\left.10^{\circ} \mathrm{S}, \mathrm{n}=30\right)$, South Subtropical gyre $\left(10\right.$ to $\left.35^{\circ} \mathrm{S}, \mathrm{n}=23\right)$ and South Temperate $\left(35\right.$ to $\left.50^{\circ} \mathrm{S}, \mathrm{n}=29\right)$ were differentiated. We used surface samples in order to test the effect of nutrient levels. For the global AMT data set, samples from the bottom of the euphotic layer were also included in the analysis. (A detailed list of sampling stations, coordinates, dates and depths is available from the authors upon request.) The combined data set spans approximately 7 orders of magnitude in abundance and cell volume. Mean nitrate concentration, chl a concentration and primary production rate were in the

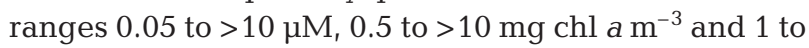
$>1000 \mathrm{mg} \mathrm{C} \mathrm{m}^{-3} \mathrm{~d}^{-1}$, respectively.

Microscopic analyses. At each station, 2 replicate seawater samples were preserved, one with $1 \%$ buffered formalin (to preserve calcium carbonate structures) and the other with $1 \%$ final concentration Lugol's iodine solution. After sedimentation of a subsample for $24 \mathrm{~h}$ (Utermöhl's technique), cells were measured and counted with an inverted microscope and identified to the lowest possible taxonomic level (usually species level). The volume of water samples used for sedimentation varied between 50 and $256 \mathrm{ml}$, according to the overall abundance of phytoplankton as shown by the fluorometer. Cell volume was calculated by assigning different geometric shapes that were most similar to the real shape of each phytoplankton species. Although data included in the present study were compiled from different databases, in general, microscopic analyses were always carried out following standard methods as explained above.

Size-abundance distributions. Size-abundance distributions were constructed for each individual community by distributing the abundance data along an octave $\left(\log _{2}\right)$ scale of cell volume. For the total abundance-size relationships, the abundance of all cells within each size class interval was summed. Population abundance-size relationships were obtained in the same way but, instead of summing the abundance of all species within each size class, their mean population abundance was determined. Finally, a mean size spectrum of total and population abundance was obtained for each analyzed ecosystem. In every case, reduced major-axis regression analysis (regression Model II) was applied to log-transformed values of abundance $\left(y\right.$-axis, cells $\left.\mathrm{ml}^{-1}\right)$ and cell volume ( $x$-axis, $\mu^{3}{ }^{3}$. The $95 \%$ confidence intervals for the regression parameters (intercept and slope) were calculated by bootstrapping over cases (2000 repetitions).

Species richness-size distributions. Species richness-size distributions were obtained for each individual community by summing the number of species within each $\log _{2}$-size class interval. Finally, the mean species richness within each size class was determined in order to obtain a single species richness-size distribution for each analyzed ecosystem. We included species $>5 \mu \mathrm{m}$ ESD. Below this size threshold, our ability to adequately identify all species making up each size class was limited by the use of conventional microscopy. Regression analyses were applied to log-transformed values of species richness ( $y$-axis, number of species $\mathrm{ml}^{-1}$ ) and cell volume $\left(x\right.$-axis, $\left.\mu^{3}\right)$. Typically, reduced major-axis regression analysis (Model II) was applied, except when both variables were not related (ANOVA, p > 0.05), in which case ordinary least-squares regression analysis (Model I) was used.

\section{RESULTS}

Total and population abundance scaled as an inverse power function of cell size (Table 1, Fig. 1). In both cases, cell size explained a significant amount of variability in phytoplankton abundance (see Table 1). Reduced major-axis regression analyses on the logtransformed data of abundance and cell size gave slopes in the range -0.74 to -1.06 for the allometric scaling of total phytoplankton abundance. Consistent with previous studies in marine and freshwater ecosystems (Sheldon et al. 1972, Sprules \& Munawar 1986, 
Table 1. Allometric scalings of total and population abundance. Log total abundance vs. $\log$ cell volume (log $N_{t}=\log C_{t}+\alpha$ $\log M)$, and $\log$ population abundance vs. $\log$ cell volume $\left(\log N_{p}=\log C_{p}+\beta \log M\right)$. Confidence limits (95\%) for the intercept and slope are given in parentheses. $n$ : number of data points included in the regression; $r^{2}$ : determination coefficient of the regression of population abundance on cell size

\begin{tabular}{|c|c|c|c|c|c|c|c|c|}
\hline Data set & $\mathrm{n}$ & $\log C_{t}$ & $\alpha$ & $\mathrm{r}^{2}$ & $\mathrm{n}$ & $\log C_{p}$ & $\beta$ & $\mathrm{r}^{2}$ \\
\hline Ría de Vigo & 17 & $\begin{array}{c}4.49 \\
(3.81,5.49)\end{array}$ & $\begin{array}{c}-0.78^{b} \\
(-1,-0.64)\end{array}$ & 0.77 & 15 & $\begin{array}{c}3.98 \\
(3.34,4.82)\end{array}$ & $\begin{array}{c}-0.73^{\mathrm{c}} \\
(-0.98,-0.58)\end{array}$ & 0.76 \\
\hline Baltic Proper & 22 & $\begin{array}{c}3.91 \\
(3.74,4.14)\end{array}$ & $\begin{array}{c}-0.79^{\mathrm{b}} \\
(-0.84,-0.72)\end{array}$ & 0.97 & 19 & $\begin{array}{c}3.67 \\
(3.39,3.67)\end{array}$ & $\begin{array}{c}-0.81^{\mathrm{c}} \\
(-0.97,-0.74)\end{array}$ & 0.98 \\
\hline Bothnia Gulf & 21 & $\begin{array}{c}3.66 \\
(3.26,4.14)\end{array}$ & $\begin{array}{c}-0.74^{\mathrm{b}} \\
(-0.86,-0.62)\end{array}$ & 0.9 & 20 & $\begin{array}{c}3.24 \\
(2.91,3.59)\end{array}$ & $\begin{array}{c}-0.73^{c} \\
(-0.83,-0.62)\end{array}$ & 0.9 \\
\hline English Channel & 19 & $\begin{array}{c}3.49 \\
(2.89,4.15)\end{array}$ & $\begin{array}{c}-0.78^{\mathrm{b}} \\
(-0.92,-0.65)\end{array}$ & 0.87 & 19 & $\begin{array}{c}2.58 \\
(2.17,3.16)\end{array}$ & $\begin{array}{c}-0.64^{\mathrm{c}} \\
(-0.77,-0.55)\end{array}$ & 0.89 \\
\hline Iberian shelf & 15 & $\begin{array}{c}3.87 \\
(3.25,4.80)\end{array}$ & $\begin{array}{c}-0.89^{\mathrm{a}} \\
(-1.09,-0.75)\end{array}$ & 0.9 & 15 & $\begin{array}{c}2.41 \\
(1.84,3.11)\end{array}$ & $\begin{array}{c}-0.68^{\mathrm{c}} \\
(-0.83,-0.56)\end{array}$ & 0.89 \\
\hline AMT global & 17 & $\begin{array}{c}3.5 \\
(2.97,4.01)\end{array}$ & $\begin{array}{c}-0.91^{\mathrm{a}} \\
(-1.04,-0.78)\end{array}$ & 0.92 & 15 & $\begin{array}{c}2.29 \\
(1.72,2.61)\end{array}$ & $\begin{array}{c}-0.73^{\mathrm{c}} \\
(-0.81,-0.59)\end{array}$ & 0.93 \\
\hline North temperate & 16 & $\begin{array}{c}3.93 \\
(3.19,4.47)\end{array}$ & $\begin{array}{c}-1^{\mathrm{a}} \\
(-1.16,-0.82)\end{array}$ & 0.91 & 15 & $\begin{array}{c}2.67 \\
(1.99,3.13)\end{array}$ & $\begin{array}{c}-0.79^{\mathrm{c}} \\
(-0.93,-0.63)\end{array}$ & 0.91 \\
\hline North subtropical & 15 & $\begin{array}{c}3.46 \\
(2.71,4)\end{array}$ & $\begin{array}{c}-1.02^{\mathrm{a}} \\
(-1.19,-0.82)\end{array}$ & 0.92 & 13 & $\begin{array}{c}2.14 \\
(1.22,2.77)\end{array}$ & $\begin{array}{c}-0.78^{\mathrm{c}} \\
(-1,-0.54)\end{array}$ & 0.85 \\
\hline Upwelling & 15 & $\begin{array}{c}3.67 \\
(2.92,4.37)\end{array}$ & $\begin{array}{c}-0.96^{\mathrm{a}} \\
(-1.14,-0.75)\end{array}$ & 0.8 & 14 & $\begin{array}{c}2.28 \\
(1.58,2.9)\end{array}$ & $\begin{array}{c}-0.74^{\mathrm{c}} \\
(-0.88,-0.56)\end{array}$ & 0.76 \\
\hline South subtropical & 14 & $\begin{array}{c}3.35 \\
(2.24,4.08)\end{array}$ & $\begin{array}{c}-1.06^{\mathrm{a}} \\
(-1.27,-0.78)\end{array}$ & 0.91 & 13 & $\begin{array}{c}1.89 \\
(1.1,2.54)\end{array}$ & $\begin{array}{c}-0.75^{\mathrm{c}} \\
(-0.95,-0.55)\end{array}$ & 0.87 \\
\hline South temperate & 16 & $\begin{array}{c}3.6 \\
(3.05,4.14)\end{array}$ & $\begin{array}{c}-0.91^{\mathrm{a}} \\
(-1.06,-0.78)\end{array}$ & 0.93 & 15 & $\begin{array}{c}2.73 \\
(1.95,3.11)\end{array}$ & $\begin{array}{c}-0.8^{\mathrm{c}} \\
(-0.94,-0.62)\end{array}$ & 0.91 \\
\hline
\end{tabular}

Cavender-Bares et al. 2001, Irwin et al. 2006), statistical analyses indicated that, for trophically similar groups, flatter slopes (i.e. not significantly different from -0.75) were associated with assemblages from productive systems, whereas steeper slopes (i.e. not significantly different from -1) were characteristic of oligotrophic environments (Table 1, Fig. 2a). Allometric scaling of population abundance yielded slopes in the range -0.64 to -0.81 . Statistical analyses indicated that, regardless of the environmental conditions, in every case the slope was not significantly different from -0.75 (2-tailed $t$-test, $\alpha=0.05, \mathrm{p}>0.05$; Table 1 , Fig. 1), in agreement with the allometric theory for population abundance (Damuth 1981). However, the regression intercept, which can be used to compare the population abundance between different ecosystems whenever slopes are identical, increased in concert with total chl a concentration, an estimate of phytoplankton biomass and thus of the ecosystem's productivity (Fig. 2b).

According to Eqs. (1) \& (2), it is possible to derive the shape of the relationship between species richness and cell size by simply dividing the allometric scalings of total and population abundance as follows:

$$
S(M)=\frac{C_{t}}{C_{p}} M^{\alpha-\beta}=C_{s} M^{\chi}
$$

where $C_{S}$ and $\chi$ are the resulting parameters (i.e. coefficient and slope, respectively) of the relationship between species richness and size (Fig. 3). To a first approximation, the model predicts that much of the across-systems variation in the size-abundance distribution is accounted for by systematic changes in the number of species along the community size spectrum (i.e. species richness-size relationship). It must be noted that because the allometric exponent of population abundance $(\beta)$ is indistinguishable from -0.75 , variability in the allometric exponent of total abundance $(\alpha)$ must be associated with changes in the slope of the relationship between species richness and size $(\chi)$. For instance, the number of large-sized species is likely to decrease compared to that of smaller species when shifting from coastal to open-ocean ecosystems, giving rise to a decrease in the slope of the relationship between total abundance and cell size. Additionally, we further determined the size distribution of species richness for each particular ecosystem, analyzing every single community independently. Consistent with expectations, empirical data indicated that the number of species rapidly decreases with cell size in oligotrophic ecosystems; however, the relationship is either a log-normal function or roughly independent of cell size in productive coastal waters (Table 2, Fig. 3). 

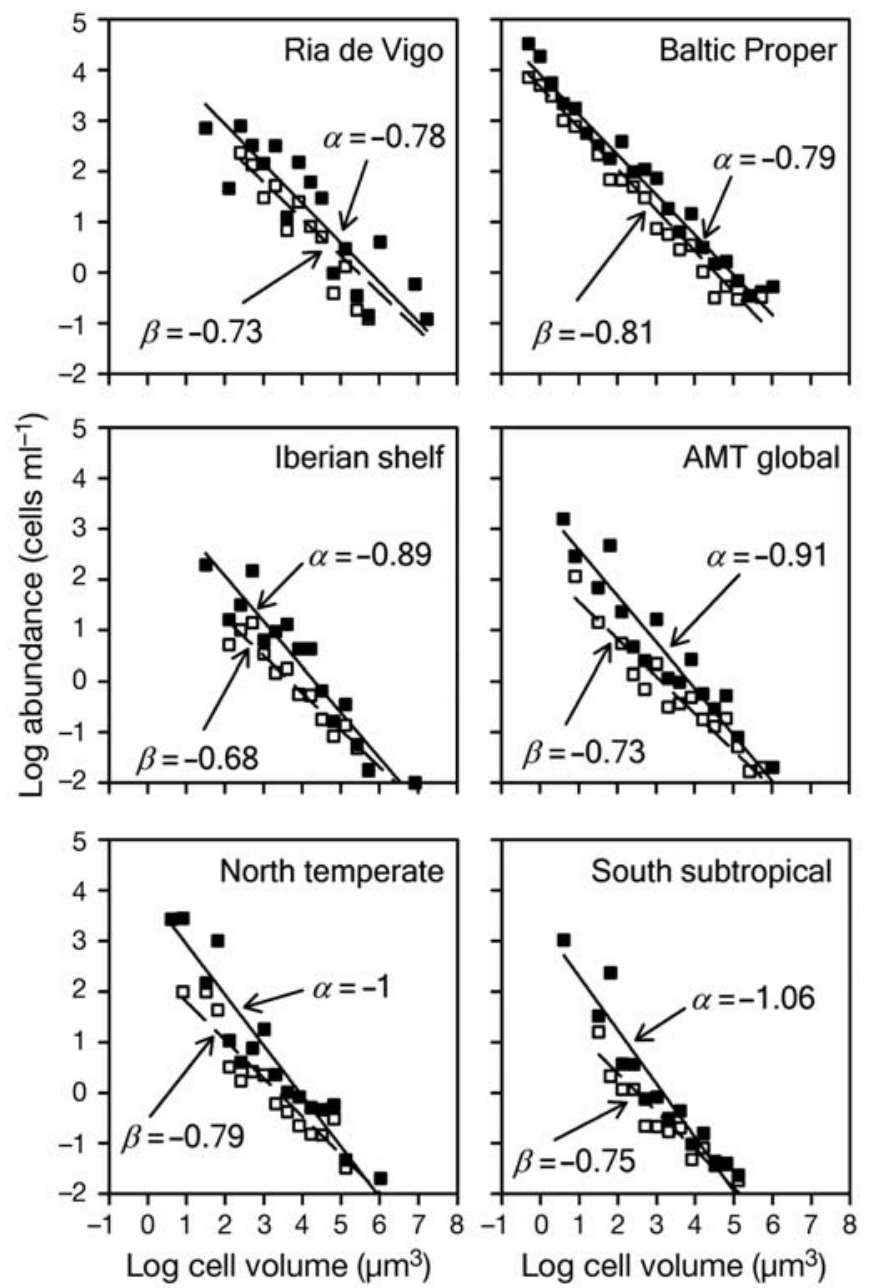

Fig. 1. Allometric scalings of total ( $\square$ ) and population abundance (ㅁ) of phytoplankton from different marine environments. Solid and dashed lines represent the best fits to logtransformed data of abundance and cell volume making up the allometric scalings of total and population abundance, respectively
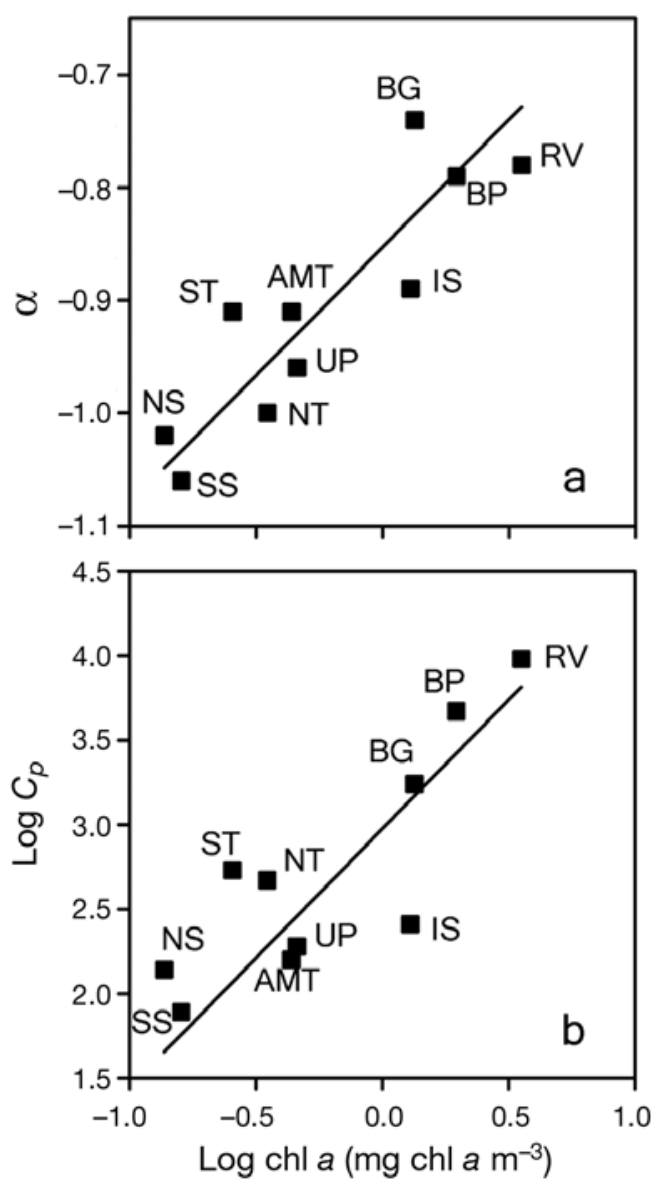

Fig. 2. Correlation analyses between the log-transformed values of chl $a$ and (a) the slope $(\alpha)$ of the allometric scaling of total abundance $(\alpha=0.2 \log$ chl $a-0.86, r=0.89, p=0.001)$, and (b) the log-transformed coefficient $\left(C_{p}\right)$ of the allometric scaling of population abundance $\left(\log C_{p}=1.2 \log \mathrm{chl} a+3.01, \mathrm{r}=\right.$ 0.85, $p=0.003)$. RV: Ría de Vigo; BP: Baltic Proper; BG: Bothnia Gulf; IS: Iberian shelf; AMT: Atlantic Meridional Transect; NT: North temperate; ST: South temperate; UP: Upwelling;

NS: North subtropical; SS: South subtropical

Table 2. Relationship between $\log$ species richness $(S)$ and $\log$ cell size $(M)$. Log-linear functions were as follows: $\log S=a+b$ $\log M$, where $a$ and $b$ parameters are analogous to $\log C_{s}$ and $\chi$, respectively. Log-normal functions were represented by the equation $f=a \exp \left[-0.5\left(\ln \left(M / M_{0} / b\right)^{2}\right]\right.$ which fits $f$ to $\log S$. n: number of data points included in the analyses; $\mathrm{r}^{2}$ : determination coefficient of the model fitted to the log-transformed data of species richness and cell size

\begin{tabular}{|c|c|c|c|c|c|c|c|}
\hline Data set & Type of function & $a$ & $b$ & $M_{0}$ & $\mathrm{n}$ & $r^{2}$ & $\mathrm{p}$ \\
\hline Ría de Vigo & Log-normal & $0.6 \pm 0.08$ & $0.34 \pm 0.08$ & $3.34 \pm 0.19$ & 17 & 0.19 & 0.0764 \\
\hline Baltic Proper & Log-linear & $0.46 \pm 0.17$ & $-0.05 \pm 0.03$ & - & 15 & 0.11 & 0.2387 \\
\hline Bothnia Gulf & Log-linear & $0.59 \pm 0.02$ & $-0.09 \pm 0.00$ & - & 14 & 0.96 & $<0.0001$ \\
\hline English Channel & Log-normal & $0.56 \pm 0.04$ & $0.2 \pm 0.04$ & $3.7 \pm 0.07$ & 15 & 0.53 & 0.0022 \\
\hline Iberian shelf & Log-normal & $0.73 \pm 0.09$ & $0.35 \pm 0.09$ & $3.1 \pm 1.8$ & 14 & 0.56 & 0.0022 \\
\hline AMT global & Log-linear & $1.06 \pm 0.08$ & $-0.18 \pm 0.02$ & - & 14 & 0.86 & $<0.0001$ \\
\hline North temperate & Log-linear & $1.05 \pm 0.12$ & $-0.17 \pm 0.03$ & - & 13 & 0.58 & 0.0024 \\
\hline North subtropical & Log-linear & $1.14 \pm 0.12$ & $-0.21 \pm 0.03$ & - & 12 & 0.76 & $<0.0001$ \\
\hline Upwelling & Log-linear & $1.12 \pm 0.09$ & $-0.19 \pm 0.02$ & - & 13 & 0.85 & $<0.0001$ \\
\hline South subtropical & Log-linear & $0.94 \pm 0.07$ & $-0.17 \pm 0.02$ & - & 14 & 0.86 & $<0.0001$ \\
\hline South temperate & Log-linear & $1.05 \pm 0.09$ & $-0.16 \pm 0.02$ & - & 14 & 0.79 & $<0.0001$ \\
\hline
\end{tabular}



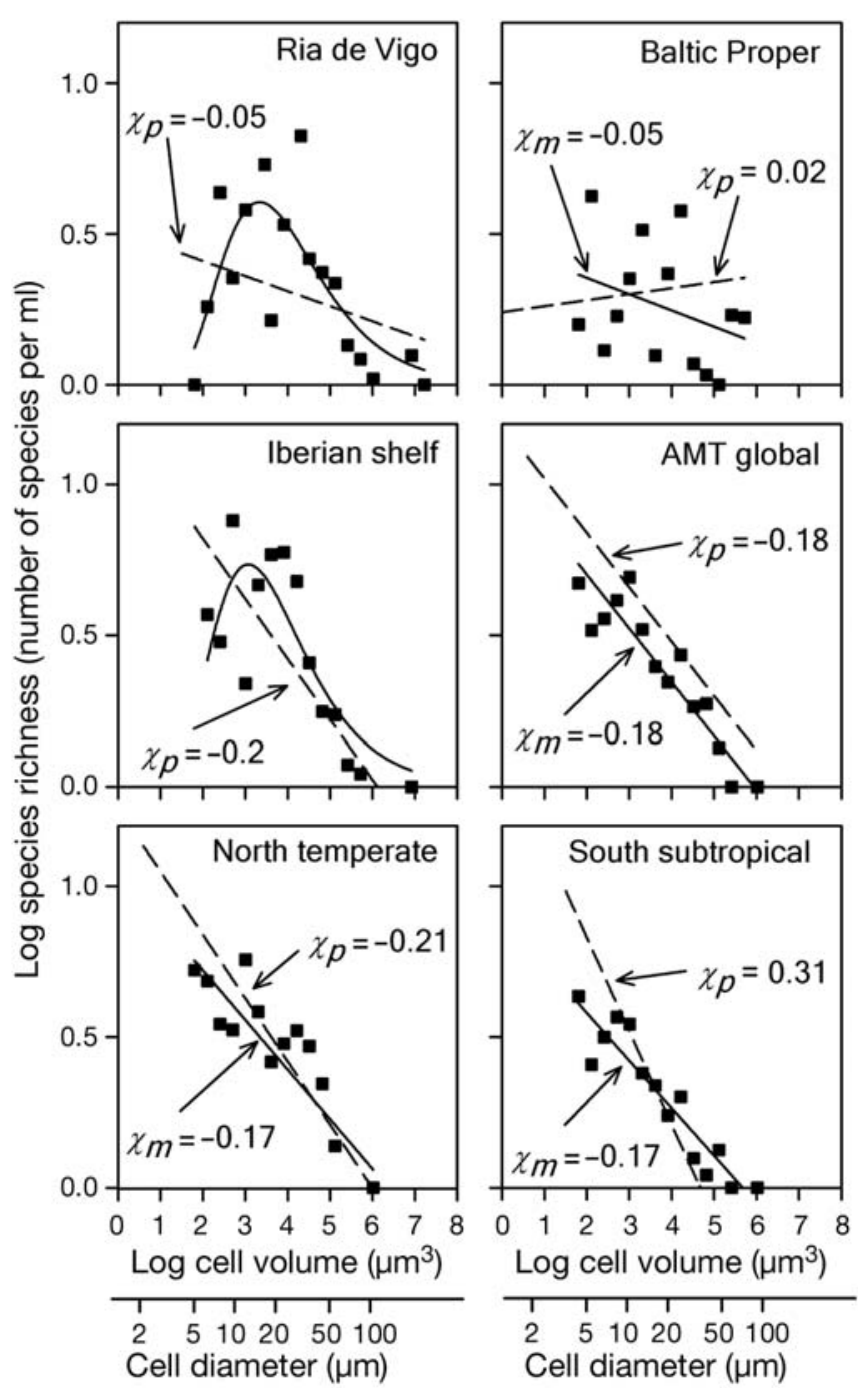

Fig. 3. Relationship between species richness and cell size from different marine environments. Solid lines are the best fits to the log-transformed values of species richness and cell volume. Dashed lines are the relationship between species richness and cell size determined by using Eq. (3) under 'Results'. $\chi_{\mathrm{m}}$ and $\chi_{\mathrm{p}}$ represent the slopes for solid and dashed lines, respectively

\section{DISCUSSION}

Phytoplankton size structure is acknowledged as a fundamental property controlling the ecological and biogeochemical functioning of pelagic ecosystems (Chisholm 1992, Kiørboe 1993). Small cells account for the bulk of phytoplankton biomass and productivity in open-ocean, oligotrophic waters, where most of the newly produced organic carbon is recycled within the euphotic layer through complex, microbial food webs. By contrast, larger cells dominate in nutrient-rich, productive waters, where a major fraction of primary production is channeled through short food chains, and ultimately, exported towards the ocean interior, thus contributing to $\mathrm{CO}_{2}$ sequestration (Chisholm 1992, Kiørboe 1993, Li 2002). Yet, despite the critical link of phytoplankton size structure to marine food webs and biogeochemical cycles, the mechanisms controlling phytoplankton size distribution in the ocean remain largely unknown.

In any ecological community, the abundance of organisms depends on 2 fundamental parameters: (1) the number of species, and (2) the population abundance (number of individuals of each species). Community size structure depends, in turn, on how each of these parameters changes with body size. We have shown that population abundance decreases consistently with body size in a similar way regardless of the environmental conditions. However, our study highlights striking variations in the relationship between number of species and cell size when shifting from open-ocean to coastal ecosystems. This finding indicates that, in contrasting marine environments, phytoplankton size structure is controlled by systematic changes in the number of species across the community size spectrum.

But what determines the shape of the relationship between species richness and cell size in phytoplankton and its across-systems variability? Over evolutionary time scales, the balance between origination and extinction processes, which ultimately determines species diversity, might be related to size-dependent metabolic constraints (Brown \& Sibly 2006). Biophysical models as well as empirical evidence indicate that an increase in phytoplankton cell radius decreases solute exchange on a volume basis due to a thicker diffusion boundary layer and a lower number of plasma membrane transporters per volume unit (Chisholm 1992, Kiørboe 1993). Assuming the simplest case of a spherical cell: a typical microalga with a radius of $10 \mu \mathrm{m}$, growing at a rate of 1 doubling $\mathrm{d}^{-1}$, is diffusionlimited at dissolved inorganic nitrogen (DIN) concentrations $<1 \mu \mathrm{M}$. At the DIN concentrations prevailing in the surface waters of oligotrophic oceans $(<0.1 \mu \mathrm{M})$, the growth rate of this microalga, supported by diffusive DIN supply, would be $<0.1 \mathrm{~d}^{-1}$ (Chisholm 1992, Kiørboe 1993). Therefore, phytoplankton in this size range are poor competitors in environments characterized by low nutrient concentrations. On the contrary, a picophytoplankton cell with a radius of $1 \mu \mathrm{m}$ could maintain a growth rate of $1 \mathrm{~d}^{-1}$ at DIN concentrations as low as $10 \mathrm{nM}$ without suffering DIN diffusion limitation. This does not mean that larger species cannot inhabit resource-limited environments such as the oligotrophic subtropical ocean. In fact, some largesized species, characteristic of subtropical regions, have evolved particular adaptive strategies that allow them to meet their resource requirements as well as 
small species do (Chisholm 1992, Cermeño et al. 2006). Over evolutionary time scales, however, the chance that large-sized species become adapted to resourcelimiting environments is relatively small compared to that of their smaller counterparts. For instance, a largesized species that incorporates by passive dispersion into the extant species pool of an oligotrophic region will experience severe metabolic constraints (i.e. nutrient acquisition), which are likely to affect its survival and evolutionary success. Large-sized species are less constrained by nutrient diffusion in resource-rich ecosystems. Therefore, under such conditions, phytoplankton diversity may be controlled either by mechanisms independent of cell size, such as species-specific abilities for nutrient exploitation (Margalef 1997) and interspecific competition for light (Huisman et al. 1999), or by trade-offs between ability for resource acquisition and refuge from predation (Kiørboe 1993). In other words, whereas small-sized cells are at an advantage in terms of resource acquisition, larger cells are less constrained by grazing pressure.

Our results do not exclude the possibility that changes in population abundance may also play a role in controlling community size structure. On average, population abundance decreases as the $-3 / 4$ power of body size. Local communities, however, exhibit considerable scatter around this overall relationship associated with environmental variability and competition for resources (Lawton 1990, Brown 1995). For instance, it is well known that, due to their ability to store nutrients in large intracellular vacuoles and high maximal growth rates, episodic inputs of nutrients into the euphotic layer lead to the onset of massive diatom blooms, with comparatively little response of smallsized phytoplankters. In this regard, it must be stressed that, across the community size spectrum, variations in cell size are accompanied by systematic changes in taxonomic composition from small picocyanobacteria to the largest diatoms. Likewise, grazing pressure may also play a key role in controlling phytoplankton size structure within local plankton communities. Grazing is likely to affect larger species less severely. The biomass and productivity of small-sized species is tightly controlled by microzooplankton, with growth rates similar to those of phytoplankton. By contrast, large phytoplankton species are grazed by mesozooplankters, with larval stages and thus longer generation times than those of phytoplankton. Therefore, the temporal uncoupling between large-sized phytoplankton species and mesozooplankton allows larger cells to proliferate whenever nutrient concentrations and light intensities remain high (Kiørboe 1993). Strikingly, despite the fact that different factors may be operating, and that local plankton communities are subject to strong temporal and spatial variability, our results reveal that large-scale patterns of phytoplankton size distribution in the ocean are controlled by systematic variations in the species richness-size relationship.

Many biological properties and community features including population abundance and species richness scale as a power function of body size. Understanding the mechanisms that control these critical relationships is a challenge in current ecology. Scaling theory is a fruitful approach to understanding these biological relationships and making connections among them (Banavar et al. 2007). Our study provides empirical evidence for one of these connections. Specifically, we show that the relationship between species richness and body size plays a crucial role in shaping the size structure of phytoplankton communities. These critical connections are likely to have their origin in the selforganization of complex adaptive systems. Ultimately, this is a result of the ecological and evolutionary processes shaping ecosystems over evolutionary time scales (Levin et al. 1997, Rinaldo et al. 2002).

In conclusion, population abundance and body size must be considered together with a third community variable, the number of species. Many studies have analyzed changes in phytoplankton size structure as a result of population dynamics, whereas comparatively little work has been devoted to the analysis of species richness-size distributions. Our results demonstrate that, over biogeographical scales, the relationship between organism size and species richness plays a critical role in controlling the size structure of ecological communities, and hence their trophic and biogeochemical functioning. Consistent with the so-called energy equivalence rule (Damuth 1981), large-sized species may process similar amounts of resources (per population species) as small species do. However, systematic changes in the size distribution of species richness ultimately dictate the way in which resources are partitioned among differently sized individuals. Therefore, understanding the way in which the number of species changes with body size is central to better understanding the size structure of microbial plankton communities and the impact on marine biogeochemical cycles.

Acknowledgements. We thank all people who contributed to the collection of data. Thanks to R. P. Harris for sharing AMT and English Channel databases and to U. Larsson, A. Andersson, O. Lindahl and L. Edler for access to the Baltic Sea database. Thanks also to E. Marañón, A. Kahl, J. P. Grover and 2 anonymous reviewers for comments on the manuscript. AMT data collection was supported by the UK Natural Environmental Research Council through the Atlantic Meridional Transect consortium (NER/O/S/2001/00680). P.C. was supported by a Fulbright Postdoctoral Research Fellowship from the Spanish Ministry of Education and Science and a Marie Curie Outgoing International Fellowship from the European Union. This is contribution 163 of the AMT program. 


\section{LITERATURE CITED}

Banavar JR, Damuth J, Maritan A, Rinaldo A (2007) Scaling in ecosystems and the linkage of macroecological laws. Phys Rev Lett 98:068104

Brown JH (1995) Macroecology. University of Chicago Press, Chicago, IL

Brown JH, Sibly RM (2006) Life-history evolution under a production constraint. Proc Natl Acad Sci USA 103: 17595-17599

Cavender-Bares KS, Rinaldo A, Chisholm SW (2001) Microbial size spectra from natural and nutrient enriched ecosystems. Limnol Oceanogr 46:778-789

Cermeño P, Marañón E, Harbour DS, Harris RP (2006) Invariant scaling of phytoplankton abundance and cell size in contrasting marine environments. Ecol Lett 9:1210-1215

Chisholm SW (1992) Phytoplankton size. In: Falkowski PG, Woodhead AD (eds) Primary productivity and biogeochemical cycles in the sea. Plenum Press, New York, p 213-237

Damuth J (1981) Population density and body size in mammals. Nature 290:699-700

> Huisman J, van Oostveen P, Weissing FJ (1999) Species dynamics in phytoplankton blooms: incomplete mixing and competition for light. Am Nat 154:46-68

Irwin A, Finkel ZV, Schofield O, Falkowski PG (2006) Scaling up from nutrient physiology to the size-structure of phytoplankton communities. J Plankton Res 28:459-471

Editorial responsibility: Howard Browman,

Storebø, Norway
Kiørboe T (1993) Turbulence, phytoplankton cell size, and the structure of pelagic food webs. Adv Mar Biol 29:1-72

Lawton JH (1990) Species richness and population dynamics of animal assemblages. Patterns in body size: abundance space. Phil Trans R Soc Lond B Biol Sci 330:283-291

Levin SA, Grenfell B, Hastings A, Perelson AS (1997) Mathematical and computational challenges in population biology and ecosystem science. Science 275:334-343

Li WKW (2002) Macroecological patterns of phytoplankton in the northwestern North Atlantic Ocean. Nature 419: $154-157$

Margalef R (1997) Our biosphere. In: Kinne O (ed) Excellence in ecology, Book 10. International Ecology Institute, Oldendorf/Luhe

Peters RH (1983) The ecological implications of body size. Cambridge University Press, Cambridge

Rinaldo A, Maritan A, Cavender-Bares KK, Chisholm SW (2002) Cross-scale ecological dynamics and microbial size spectra in marine ecosystems. Proc R Soc Lond B Biol Sci 269:2051-2059

Rodríguez J (1994) Some comments on the size-based structural analysis of the pelagic ecosystem. Sci Mar 58:1-10

Sheldon RW, Prakash A, Sutcliffe WH (1972) The size distribution of particles in the ocean. Limnol Oceanogr 17: $327-340$

Sprules WG, Munawar M (1986) Plankton size spectra in relation to ecosystem productivity, size, and perturbation. Can J Fish Aquat Sci 43:1789-1794

Submitted: July 2, 2007; Accepted: October 21, 2007 Proofs received from author(s): March 16, 2008 